\title{
CAMBRIDGE
}

\section{A Concise History of Greece}

RICHARD CLOGG

Provides a concise, illustrated introduction to the history of modern Greece, from the first stirrings of the nationalist movement in the late eighteenth century to the present day. f22.95 net HB 0521372283 200pp. f8.95 net PB 0521378303

Cambridge Concise Histories

\section{Contending with Hitler}

Varieties of German Resistance in the Third Reich

\section{Edited by DAVID CLAY LARGE}

A distillation of recent scholarship on Germany's domestic resistance to the Nazi dictatorship, including investigations of resistance efforts by Jews, women, workers, and young people. Former West German chancellor, Willy Brandt, contributes by highlighting the Socialist opposition. £24.95 net HB 0521414598 208pp.

\section{A Distinct Industrialization}

Cotton in Barcelona, 1728-1832

\section{J. K. J. THOMSON}

This is a study of the early development of Barcelona's cotton industry. It offers both a specialised industrial history and an interpretation of major issues relating to the industrialization of Catalonia and of Europe as a whole. f50.00 net HB 0521394821 320pp.
A History of the Peoples of Siberia

Russia's North Asian Colony 1581-1990

JAMES FORSYTH

This is the first ethnohistory of Siberia to appear in English, and presents to an anglophone audience a vast corpus of previously inaccessible ethnographic and linguistic material.

f50.00 net HB 0521403111 528pp.

\section{Liberty, Retrenchment and Reform}

Popular Liberalism in the Age of Gladstone, 1860-1880

EUGENIO F. BIAGINI

This book offers a radically innovative synthesis of the history of popular support for the Liberal party during the second half of the nineteenth century and examines the people who supported it, their beliefs, and the way in which those beliefs related to one another and to reality. f45.00 net HB 0521403154 495pp.

\section{Church and City, 1000-1500}

\section{Essays in Honour of Christopher Brooke}

Edited by DAVID ABULAFIA, MICHAEL FRANKLIN and MIRI RUBIN A volume of essays which explore two important areas in medieval history: urban life and religious life. Each essay examines a case of interaction between religious ideas, institutions and practises, and urban institutions and the townsfolk, within medieval towns.

E55.00 net HB 0521356113 300pp. 


\section{HISTORY}

Edited by W A Speck

History, one of the leading

Recent articles include:

joumals in its field, packs into

its 576 pages a variety of articles, review articles, book

reviews and editorial notes. The

Tax Reform and Rebellion in

Early Tudor England

Michael Bush

joumal publishes articles which illuminate problems on all aspects of history, in very

The Moscow Declaration, the

Kharkov Trial and the

different periods and historical

Question of a Policy on

areas.

Published by Blackwell

Publishers on behalf of the

Major War Criminals in the

Second World War

Arieh J. Kochavi

Historical Association.

ORDER FORM

Subscription Rates, Volume 77, 1992 ISSN 0018-2648

HISTORY

Individuals and Institutions

\$35.00 (UKVEurope), $\$ 66.00$ (N America), 839.00 (Rest of World)

Published February, June, October

$\square \quad$ Please enter my subscription/send me a sample copy

口 I enclose a cheque/money order payable to Basll Blackwell

口 Please charge my Access/American Express/Diners

Club/Mastercard/Nisa acoount number

Expiry Date

For payments via the National Girobank, the Blackwell account number is 2366053

Name

Address

Postcode

Signature

Date

Payment must scocompeny ordere

Pleace retum this form w: Journals Marketing Manager, Bleckwall Publishers, 108 Cowloy

Foad, Oxford, OX4 1JF, England. Regletered No. 180277 . Or bo Journals Marketing, HIST.

Bleckwell Publishers. Three Combridge Center. Comberldge, MA O2142, USA

Oxford and Cambridge MA 


\section{HISTORICAL RESEARCH}

\section{The Bulletin of the Institute of Historical Research}

\section{Edited by P K O'Brien}

Historical Research is one of the leading British historical journals. It publishes the work of established historians, and also aims to encourage young historians. The journal's articles exploit new sources, examine familiar sources in new ways, or re-examine received views in the light of fresh evidence.
Recent Articles include: William the Conqueror and the Anglo-Norman Succession Barbara English

City and Country in the past EA Wrigley

Germans in Britain During the First World War $P$ Panayi

\section{ORDER FORM}

Subscription Rates, Volume 65, 1992

HISTORICAL RESEARCH

Individuals \$16.00 (UKE ETOpo), \$34.00 (N America), 220.00 (Rost of World)

Institutions 830.00 (UK/Europe), $\$ 65.00$ (N America), 238.50 (Rest of World)

Published three times a year

$\square \quad$ Please enter my subscription/send me a sample copy

I enclose a cheque/money order made payable to Basil Blackwell

Please charge my Access/American Express/Diners Club/ MastercardNisa account number

Expiry Date

For payments via the National Girobank, the Blackwell account number is 2366053

Name

Address

Postcode

Signature Date

Payment must accompany orders

Please retum this form to: Journals Marketing Manager, Blackwell Publishers, 108 Cowley Road, Oxford OX41JF, England. Registered No. 180277. Or to: Joumals Marketing, HISR, Blackwell Publishers, Three Cambridge Center, Cambridge, MA 02142, USA

\section{Blackwell Publishers Oxford and Cambridge MA}




\title{
REVUE FRANÇAISE D'HISTOIRE D'OUTRE-MER explorations, colonisations, indépendances
}

\author{
Éditee par
}

CharLes-Robert AGERON, Université Paris XII

Volume 79

$n^{\circ} 294$ (1ex trimestre 1992)

Eugène-Abdon MAgE: Je vous écris de Ségou. Lettres présentées et commentees par Yves-Jean SAINT-MARTIN.

William J. SAMARIN : La politique indigène in the history of Bangui.

Roger JOINT-DAGUENET : La côte africaine du golfe d'Aden au milieu $d u x I x^{e} s$. NOTES DE LECTURE :

Daniel RIVET : Histoire de la France coloniale.

Roger PASQUIER : L'histoire des missions. Nouvelles approches.

COMPIES RENDUS.

$n^{\circ} 295$ (2 $2^{e}$ trimestre 1992)

Thomas Schoonover : France in Central America 1820-1929. An overview.

Marc MicheL : De Lattre, la conférence de Singapour et ses suites, mai 1951.

André KASPI : La mission du général de Lattre aux Etats-Unis, 13-25 septembre 1951.

Ulrike SCHORKENS : Le travail forcé au Togo sous mandat français, 1919-1941.

NOTES DE LBCTURE :

Martin STEINS : "La Forza del destino ». L.S. Senghor aux mains des hagiographes.

Jean-Luc VELLUT : La lecture des signes de la pauvreté dans le passé et le présent de l'Afrique tropicale et australe.

COMPTES RENDUS

Prix du numéro : 95 FF

Conditions d'abonnement (4 numéros par an)

France : $290 \mathrm{FF}$ Étranger: $340 \mathrm{FF}$ supplément avion $60 \mathrm{FF}$

SOCIÉTE FRANÇAISE D'HISTOIRE D'OUTRE-MER

9 rue Robert-de-Flers, 75015 Paris, FRANCE 


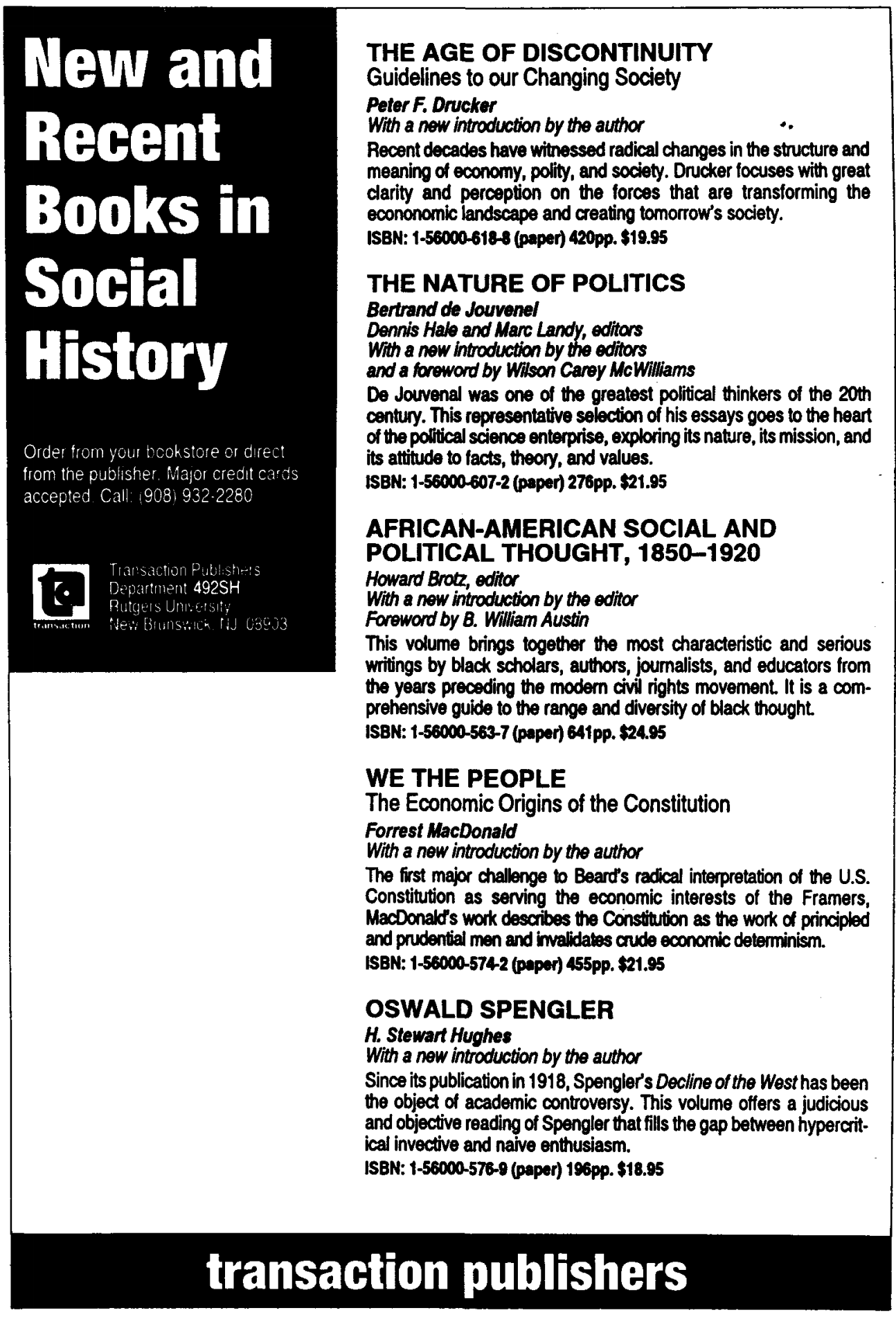




\section{Life in Ancient Egypt EUGEN STROUHAL}

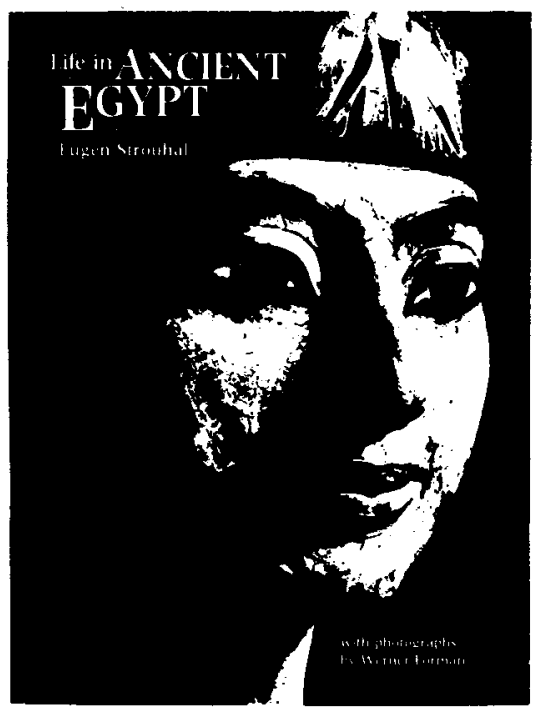

The most comprehensive exploration of everyday life in Ancient Egypt ever published

Beautifully illustrated in colour throughout, this book represents a major addition to our knowledge of Ancient Egypt. The author uses a wealth of literary, physical and artistic evidence to recreate the life of the Ancient Egyptians from conception and birth to death and burial, covering everything from the high infant mortality to the common causes of death; from the primitive working methods of farmers, fishermen and hunters to the impressive achievements of scientists, mummificators and physicians.

Also discussed are issues such as the role of women, fashion, the frequent epidemics, and the growing problems of hygiene and sanitation.

The text is complemented throughout by superb colour photographs, many taken specially for the book. f24.95 net HB 0521440939280 pp. 1992 


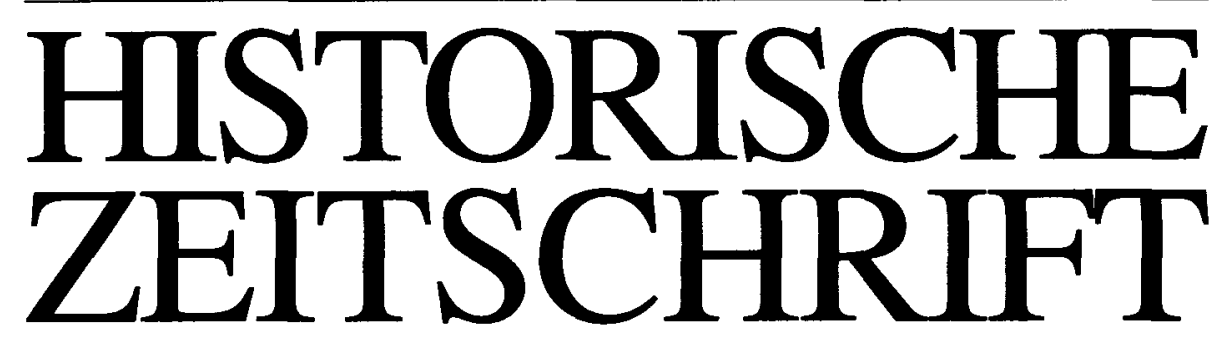

The extremely valuable source of information on European History.

The HISTORISCHE ZEITSCHRIFT began publication in 1859. This review, edited by Professor Lothar Gall, offers an outstanding forum for debate on German and international history. Its essays, its book reviews and its bibliographical notes provide a comprehensive picture of German and international history.

For all those concerned with history the HISTORISCHE ZEITSCHRIFT is a must.

The HISTORISCHE ZEITSCHRIFT is published six times a year, in February, April, June, August, October and December.

The annual subscription price 1992 (=6 issues, approx. 280 pages each) is DM380,-plus postage.

Subscribers of HISTORISCHE ZEITSCHRIFT can obtain on special conditions the supplements „Sonderhefte“ and „Beihefte“.

\section{Contents of Vol. 255/no. 2 (Oktober 1992):}

Johannes Fried: Kunst und Kommerz. Über das Zusammenwirken von Wissenschaft und Wirtschaft im Mittelalter vornehmlich am Beispiel der Kaufleute und Handelsmessen.

Leonhard Harding: Faszination Afrikanische Geschichte: Afrikanische Händler zwischen Gesellschaft und Geschäft.

Johannes Paulmann: Arbeitsmarktpolitik in Großbritannien von der Zwischenkriegszeit bis in die Zeit nach dem Zweiten Weltkrieg.

Hedwig Röckelein: Historische Frauenforschung. Ein Literaturbericht zur Geschichte des Mittelalters.

If you would like to know more about our journal, we will be pleased to send you the last issue of HISTORISCHE ZEITSCHRIFT.

R. Oldenbourg Verlag, P. O. Box 8013 60, D - 8000 München 80

\section{Oldenbourg}


I All contributions, correspondence, and books for review should be sent to: The Editors, The Historical Joumal, Faculty of History, West Road, Cambridge CB3 9EF.

2 The Historical foumal publishes articles on all aspects of history since the fifteenth century.

3 Articles must not exceed io,000 words and communications 5,000 words in length.

4 Contributions should be typed double-spaced on $\mathrm{A}_{4}$ paper, with footnotes typed separately at the end of the contribution, and must observe the typographical and stylistic conventions of the foumal. A style-sheet is available from the Editors on request.

5 Authors should submit the top copy of their typescript and keep another copy to assist in their correction of proofs.

6 Submission of an article is taken to imply that it has not previously been published, and is not being considered for publication elsewhere. Authors are also asked to provide brief details of any related article or book they are publishing elsewhere.

7 Authors who wish their contributions to be returned if not accepted for publication are asked to enclose return postage or international postage coupons. 


\section{THE \\ HISTORICAL \\ JOURNAL}

VOLUME 36, I MARCH I993

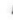

CONTENTS

ARTICLES

G. W. Bernard Anne Boleyn's religion

Hiram Morgan Hugh O'Neill and the Nine Years War in Tudor Ireland 2I

Mark Knights London's 'Monster' Petition of 1680

Sharon Kettering Brokerage at the court of Louis XIV

P. G. M. Dickson Joseph II's reshaping of the Austrian church

Christina Rathgeber The reception of Brandenburg-Prussia's new

Lutheran Hymnal of $178 \mathrm{I}$

Henry Horwitz and James Oldham John Locke, Lord Mansfield, and arbitration during the eighteenth century

Feremy Smith Bluff, bluster and brinkmanship: Andrew Bonar Law and

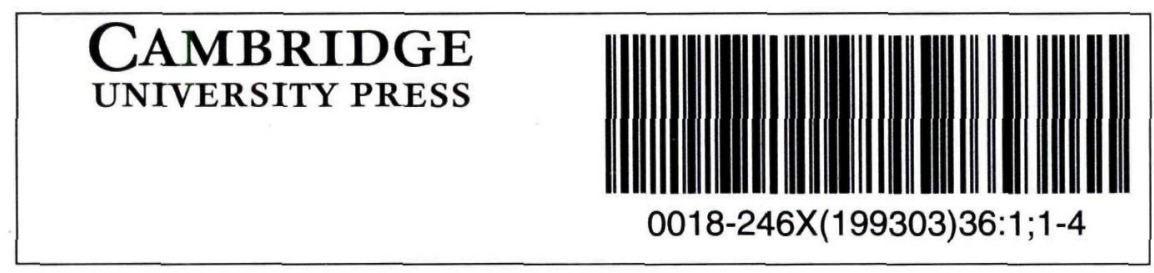

